\title{
An improved process-oriented hydro-biogeochemical model for simulating dynamic fluxes of methane and nitrous oxide in alpine ecosystems with seasonally frozen soils
}

\author{
Wei Zhang ${ }^{1}$, Zhisheng Yao ${ }^{1}$, Siqi Li ${ }^{1}$, Xunhua Zheng ${ }^{1,2}$, Han Zhang ${ }^{1,3}$, Lei Ma ${ }^{1,4}$, Kai Wang ${ }^{1}$, Rui Wang ${ }^{1}$, \\ Chunyan Liu ${ }^{1}$, Shenghui Han ${ }^{1}$, Jia Deng ${ }^{5}$, and Yong Li $^{1}$ \\ ${ }^{1}$ State Key Laboratory of Atmospheric Boundary Layer Physics and Atmospheric Chemistry, \\ Institute of Atmospheric Physics, Chinese Academy of Sciences, Beijing 100029, P. R. China \\ ${ }^{2}$ College of Earth and Planetary Sciences, University of the Chinese Academy of Sciences, Beijing 100049, P. R. China \\ ${ }^{3}$ School of Geographic and Environmental Sciences, Tianjin Normal University, Tianjin 300387, P. R. China \\ ${ }^{4}$ Institute of Meteorology and Climate Research, Atmospheric Environmental Research (IMK-IFU), \\ Karlsruhe Institute of Technology, Kreuzeckbahnstrasse 19, 82467 Garmisch-Partenkirchen, Germany \\ ${ }^{5}$ Complex Systems Research Center, Institute for the Study of Earth, Oceans, and Space, \\ University of New Hampshire, 39 College Road, Durham, NH 03824, USA
}

Correspondence: Xunhua Zheng (xunhua.zheng@post.iap.ac.cn)

Received: 20 November 2020 - Discussion started: 13 January 2021

Revised: 27 May 2021 - Accepted: 14 June 2021 - Published: 14 July 2021

\begin{abstract}
The hydro-biogeochemical model Catchment Nutrient Management Model - DeNitrification-DeComposition (CNMM-DNDC) was established to simultaneously quantify ecosystem productivity and losses of nitrogen and carbon at the site or catchment scale. As a process-oriented model, this model is expected to be universally applied to different climate zones, soils, land uses and field management practices. This study is one of many efforts to fulfill such an expectation, which was performed to improve the CNMM-DNDC by incorporating a physically based soil thermal module to simulate the soil thermal regime in the presence of freeze-thaw cycles. The modified model was validated with simultaneous field observations in three typical alpine ecosystems (wetlands, meadows and forests) within a catchment located in seasonally frozen regions of the eastern Tibetan Plateau, including observations of soil profile temperature, topsoil moisture, and fluxes of methane $\left(\mathrm{CH}_{4}\right)$ and nitrous oxide $\left(\mathrm{N}_{2} \mathrm{O}\right)$. The validation showed that the modified CNMM-DNDC was able to simulate the observed seasonal dynamics and magnitudes of the variables in the three typical alpine ecosystems, with index-of-agreement values of $0.91-1.00,0.49-0.83,0.57-0.88$ and $0.26-0.47$, respectively. Consistent with the emissions determined from
\end{abstract}

the field observations, the simulated aggregate emissions of $\mathrm{CH}_{4}$ and $\mathrm{N}_{2} \mathrm{O}$ were highest for the wetland among three alpine ecosystems, which were dominated by the $\mathrm{CH}_{4}$ emissions. This study indicates the possibility for utilizing the process-oriented model CNMM-DNDC to predict hydrobiogeochemical processes, as well as related gas emissions, in seasonally frozen regions. As the original CNMM-DNDC was previously validated in some unfrozen regions, the modified CNMM-DNDC could be potentially applied to estimate the emissions of $\mathrm{CH}_{4}$ and $\mathrm{N}_{2} \mathrm{O}$ from various ecosystems under different climate zones at the site or catchment scale.

\section{Introduction}

During the last 50 years, extraordinary changes in the nitrogen and carbon cycles, which are essential components of ecosystems, have occurred globally (e.g., Galloway et al., 2008; Canfield et al., 2010). Climate changes due to warming and anthropogenic activities derived from food production have significantly altered the cycling of nitrogen and carbon and have led to increased reactive nitrogen availability and carbon losses, which result in a series of environmental 
problems at the catchment, regional and even global scales (e.g., Galloway et al., 2004, 2008; Ju et al., 2009). Excessive reactive nitrogen in soils can be lost in the forms of nitrogen gases, such as nitrous oxide $\left(\mathrm{N}_{2} \mathrm{O}\right)$, nitric oxide $(\mathrm{NO})$ and ammonia $\left(\mathrm{NH}_{3}\right)$, and nitrogen pollution, such as nitrate $\left(\mathrm{NO}_{3}^{-}\right)$and ammonium $\left(\mathrm{NH}_{4}^{+}\right)$, in water through leaching or surface runoff (e.g., Seitzinger, 2008; Collins et al., 2016). In the face of increased air temperatures and intensive land use changes, especially in cold regions, the soil organic carbon stored since the Last Glacial Maximum has been lost to the atmosphere via methane $\left(\mathrm{CH}_{4}\right)$ and carbon dioxide $\left(\mathrm{CO}_{2}\right)$ (e.g., Piao et al., 2009; Fenner and Freeman, 2011; Schuur et al., 2015). These nitrogen and carbon losses contribute to potential global warming $\left(\mathrm{CO}_{2}, \mathrm{CH}_{4}\right.$ and $\left.\mathrm{N}_{2} \mathrm{O}\right)$, air pollution $\left(\mathrm{NO}\right.$ and $\left.\mathrm{NH}_{3}\right)$ and surface/groundwater pollution $\left(\mathrm{NO}_{3}^{-}\right.$and $\mathrm{NH}_{4}^{+}$). Therefore, sustainable ecosystems urgently need to be established that not only focus on net primary productivity but also are friendly to the environment with minimal hazards such as greenhouse gases, air pollution and water pollutants (e.g., Cui et al., 2018; Zhang et al., 2019).

The cycling of nitrogen and carbon is closely related to soil water processes (e.g., Breuer et al., 2010; Vereecken et al., 2016; W. Zhang et al., 2018). Thus, interactions among soil waters and the cycling of nitrogen and carbon govern biological productivity and environmental outcomes (e.g., Zhu et al., 2018). The interactions consist of the redox potential for different transformation processes influenced by the spatiotemporal variation in soil water content and the lateral transport of water and dissolved nitrogen or carbon controlled by surface and subsurface flow (e.g., McClain et al., 2003; Castellano et al., 2013; Bechmann, 2014). For example, the variation in soil water content can create hot spots or moments of nitrogen and carbon losses by influencing plant nitrogen uptake, redox potential, and the transport of dissolved nitrogen and carbon (e.g., Zhu et al., 2012; Keiluweit et al., 2017). Therefore, a complete understanding of biogeochemical processes will inevitably involve interactions among soil water and the cycling of nitrogen and carbon (e.g., Breuer et al., 2010; Vereecken et al., 2016; Zhu et al., 2018).

Biogeochemical models, such as DNDC, LandscapeDNDC, WNMM, MOMOS, CENTURY and DayCent, are effective tools for simulating the cycling of nitrogen and carbon and quantifying the effects of climate change and anthropogenic activities on ecosystems (e.g., Foereid et al., 2007; Haas et al., 2012; Li, 2007; Li et al., 2007; Pansu et al., 2010; Cheng et al., 2014; Pansu et al., 2014). In recent years, some new conceptual approaches have been applied in the biogeochemical models, such as centering on the functional role of the soil microbial biomass (Pansu et al., 2010, 2014) and detailing the lateral transport of water and nutrients (Haas et al., 2012; W. Zhang et al., 2018). Generally, comprehensive hydrological processes, especially for the lateral transport of water and nutrients, are simplified or ignored in most models due to specific questions that must be addressed (e.g., Li, 2007; Li et al., 2007; Chen et al., 2008; Deng et al., 2014).
For the land surface or hydrological models at large scales, they are designed with explicit mechanisms of hydrology and generally focus on vertical and lateral nutrient transport, such as nitrate loads into rivers (e.g., Liu et al., 2019). However, the simulations of nitrogen and carbon processes are usually based on empirical functions even without predicting gas loss. Due to the various purposes of different models, coupling soil hydrological models with biogeochemical models can be an effective strategy for integrating soil water and cycling of nitrogen and carbon to improve model performance. Thus, the coupled model with improved performance can be applied to simultaneously predict productivity and potential negative environmental effects (e.g., Chen et al., 2008; Zhu et al., 2018).

In recent years, efforts have been implemented to couple models, such as SWAT-N, LandscapeDNDC-CMF, APSIM, SWAT-DayCent and the CNMM-DNDC (e.g., Pohlert et al., 2007; Haas et al., 2012; Holzworth et al., 2014; Wu et al., 2016; W. Zhang et al., 2018; Zhang et al., 2016). The models derived from SWAT were all based on semidistributed hydrological models using hydrologic response units and did not perform better in estimating non-point source pollution (e.g., Pohlert et al., 2007; Bosch et al., 2011; $\mathrm{Wu}$ et al., 2016). A coupler was used to couple two models for LandscapeDNDC-CMF, which realized the simulation of horizontal movement of water and nutrients (e.g., Haas et al., 2012; Klatt et al., 2017; Schroeck et al., 2019). Compared with other models, the Catchment Nutrient Management Model - DeNitrification-DeComposition (CNMMDNDC), which was established by incorporating the core biogeochemical processes of DNDC into the hydrological framework of the CNMM, was validated at a catchment with complex landscapes in the subtropical region and showed good performance for simultaneously simulating various variables, including ecosystem productivity, hydrological nitrogen losses and nitrate discharge in streams, and emissions of gaseous carbon and nitrogen (W. Zhang et al., 2018). Therefore, the CNMM-DNDC has the capacity to simulate the various variables closely related to both productivity and environmental hazards.

However, as a process-oriented hydro-biogeochemical model designed to be applicable to different climate zones, soils, land uses and field management practices, CNMMDNDC testing is still lacking due to limited observations for model validation. In this study, the model was applied to a catchment in a seasonally frozen region located on the eastern Tibetan Plateau with the land use types of alpine wetlands, meadows and forests to test its ability to simulate hydro-biogeochemical processes. However, scientific descriptions of soil thermal dynamics due to freeze-thaw cycles are still lacking for the CNMM-DNDC. This gap may hinder model application in seasonally frozen regions, which account for $56 \%$ of the exposed land surface of the Northern Hemisphere (Jiang et al., 2020). In addition, the soil freezethaw cycles that occur in these middle- and high-latitude re- 
gions exert important influences on soil thermal dynamics, as well as on related hydrological processes, thus increasing the availability of substrates and stimulating the processes of $\mathrm{CH}_{4}$ and $\mathrm{N}_{2} \mathrm{O}$ production and emissions in soils (e.g., Song et al., 2019). Therefore, we hypothesize that adding the missing scientific processes of soil thermal dynamics into the internal model program codes can improve the performance of the CNMM-DNDC in simulating the soil thermal dynamics, hydrological processes, and $\mathrm{CH}_{4}$ and $\mathrm{N}_{2} \mathrm{O}$ fluxes in seasonally frozen regions. Filling this gap is especially necessary to broaden model applicability.

To test the above hypothesis, the catchment simulation in the Rierlangshan catchment was conducted using a unique experimental dataset, which was obtained by $\mathrm{H}$. Zhang et al. $(2018,2019)$ and Yao et al. (2019) for the catchment that involved three typical alpine ecosystems - wetlands, meadows and forests - on the eastern Tibetan Plateau. The aims of this study were to (i) attempt to address the gap in the CNMM-DNDC by improving the scientific processes of soil thermal dynamics for seasonally frozen regions and (ii) compare the performances of the original and modified models in simulating the soil profile temperature, topsoil moisture, and $\mathrm{CH}_{4}$ and $\mathrm{N}_{2} \mathrm{O}$ fluxes in three typical alpine ecosystems in the Rierlangshan catchment with field observations. Therefore, the validated model with modifications provides a mechanism for not only interpreting observations but also predicting the $\mathrm{CH}_{4}$ and $\mathrm{N}_{2} \mathrm{O}$ fluxes in alpine ecosystems.

\section{Materials and methods}

\subsection{Model description}

\subsubsection{Overview of the CNMM-DNDC}

The CNMM-DNDC is a process-oriented model developed for simulating hydro-biogeochemical interactions at the catchment or site scale. This model is designed following the basic theories of physics, chemistry and biogeochemistry and has the capacity to simulate the complex transport and transformation of water, nitrogen and carbon in terrestrial ecosystems under both aerobic and anaerobic conditions. The model can be applied to simultaneously quantify ecosystem productivity, net emissions of nitrogen and carbon gases, and hydrological nitrogen losses through soil leaching and discharge in streams from an entire catchment or individual landscape unit (W. Zhang et al., 2018). The model was established to address the bottleneck issue associated with most biogeochemical models, i.e., the inability to simulate the lateral flows of water and nutrients, by incorporating the core biogeochemical processes of DNDC (including the processes of decomposition, nitrification, denitrification and fermentation) into the hydrological framework of the CNMM, which is fully distributed. For the new generation of biogeochemical models, the microbial ecology was inte- grated into the biogeochemical models, which represents direct microbial control over decomposition, such as MOMOS (Pansu et al., 2010; Treseder et al., 2011; Todd-Brown et al., 2012; Pansu et al., 2014). The biogeochemical processes simulated by DNDC were generally based on first-order kinetics for decomposition and Michaelis-Menten kinetics of two substrates for nitrification and denitrification, which only considered the parameterized growth and death of nitrifiers and denitrifiers $(\mathrm{Li}, 2000)$. However, due to the global application and validation of DNDC (e.g., Chen et al., 2008; Giltrap et al., 2010; Cui et al., 2014; Zhang et al., 2015), the biogeochemical processes of DNDC were selected in the CNMM-DNDC despite some deficiencies in simulating microbial biomass.

The simulated soil depth (including bedrock) is userdefined. The temporal and spatial resolutions are also userdefined according to the driving data of climate (generally in $3 \mathrm{~h}$ intervals) and digital elevation model (DEM). The soil moisture was calculated based on the mass balance of precipitation, irrigation, evapotranspiration, vertical flow, lateral flow and water from a rising water table. The total water that can be infiltrated during each time step was determined by a defined maximum infiltration rate. Darcy's law was applied for predicting the vertical water flow in the soil profile. A cell-by-cell approach using a kinematic approximation was applied to route the saturated overland and subsurface flow based on the DEM. The streamflow was estimated using a cascade of linear channel reservoirs (Wigmosta et al., 1994). For plant growth, gross primary production was simulated using Farquhar et al. (1980) for $\mathrm{C}_{3}$ and Collatz et al. (1992) for $\mathrm{C}_{4}$, with net primary productivity calculated as the residue of gross primary production and autotrophic respiration. The processes related to the production of $\mathrm{N}_{2} \mathrm{O}$ include nitrification and denitrification, which occur simultaneously at aerobic and anaerobic microsites, respectively. The concept of an "anaerobic balloon" was adopted to determine the microsites and allocate substrates for nitrification and denitrification. The sizes of the aerobic (nitrification) and anaerobic (denitrification) microsites were determined by the soil redox potential (Eh) using the Nernst equation ( $\mathrm{Li}, 2007)$. The "hole-in-the-pipe" concept was applied to calculate $\mathrm{N}_{2} \mathrm{O}$ production during nitrification, which is influenced by the soil moisture, temperature and $\mathrm{pH}(\mathrm{Li}, 2016)$. The production of $\mathrm{N}_{2} \mathrm{O}$ during denitrification was predicted with Michaelis-Menten kinetics and Pirt functions following the reaction chain of denitrification. The predicted $\mathrm{CH}_{4}$ flux was influenced by $\mathrm{CH}_{4}$ production, oxidation and transportation derived from the module of fermentation in DNDC ( $\mathrm{Li}, 2007)$. Methane production and oxidation occurred simultaneously and were determined by the sizes of the aerobic (oxidation) and anaerobic (production) microsites, which were defined by an Eh calculator in terms of an anaerobic balloon (" $\mathrm{CH}_{4}$ balloon") ( $\left.\mathrm{Li}, 2007\right)$. The predicted $\mathrm{CH}_{4}$ production was calculated from the carbon substrates resulting from decomposed soil organic carbon (SOC) and plant root 
biomass with the effects of soil temperature (Li, 2000, 2016). For more details, please see Li $(2000,2007)$ and W. Zhang et al. (2018).

\subsubsection{Modifications of the CNMM-DNDC}

In the CNMM-DNDC, the soil temperature was predicted by solving the one-dimensional heat conduction equation with the implicit method of Crank-Nicolson. However, despite the simple parameterization used for the calculation of soil heat capacity and thermal conductivity, the variations in soil temperature induced by the freeze-thaw cycles were also not considered (Table S1 of the online Supplement), which inevitably hindered its application in seasonally frozen regions. In this study, the CNMM-DNDC was modified by replacing the above soil thermal module by a physically based module of Northern Ecosystem Soil Temperature (Zhang et al., 2003; Deng et al., 2014), which can explicitly describe the energy exchange within the soil, the active layer dynamics and the soil thermal regime in the presence of freeze-thaw cycles. These modifications are indispensable for accurately simulating freeze-thaw cycles in seasonally frozen regions, which are crucial for characterizing the active layer and soil thermal dynamics, soil hydrology, and nitrogen or carbon cycling in these regions. Therefore, the CNMM-DNDC with and without the modifications is hereafter referred to as the original and modified model, respectively.

The modified thermal dynamics of the soil are calculated by the one-dimensional heat conduction equation (Eq. 1). The equation is solved numerically by converting it to an explicit form (Eqs. 2-4), which is more efficient for considering the freeze-thaw cycles (Zhang et al., 2003). In the following equations, $C\left(\mathrm{~J} \mathrm{~m}^{-3}{ }^{\circ} \mathrm{C}^{-1}\right), k\left(\mathrm{~W} \mathrm{~m}^{-1}{ }^{\circ} \mathrm{C}^{-1}\right), T\left({ }^{\circ} \mathrm{C}\right)$ and $G\left(\mathrm{~W} \mathrm{~m}^{-2}\right)$ denote the soil heat capacity, thermal conductivity, soil temperature and heat fluxes between layers, respectively. Both $Z$ and $D$ are the thicknesses of the soil layer (m); $t$ is the time step of the calculation, and $l$ denotes the soil layer. $S$ is the internal heat exchange due to freezing or thawing $\left(\mathrm{W} \mathrm{m}^{-3}\right)$ when the soil temperature is around $0^{\circ} \mathrm{C}$. The soil temperature changes affected by freezing or thawing are determined on the basis of energy conservation. The latent heat released during freezing equals the amount of heat required for the increased soil temperature and vice versa. The dynamic soil heat capacity $\left(C_{l}, \mathrm{~J} \mathrm{~m}^{-3}{ }^{\circ} \mathrm{C}^{-1}\right)$ is the weighted average of the heat capacity for five constituents, including organic matter $\left(C_{l, \mathrm{OM}}\right)$, minerals $\left(C_{l, \mathrm{Min}}\right)$, water $\left(C_{l \text {,Water }}\right)$, ice $\left(C_{l \text {,Ice }}\right)$ and air $\left(C_{l, \text { Air }}\right)($ Eq. 5$)$. The values of heat capacity for organic matter, minerals, water, ice and air were $2.5 \times 10^{6}, 2.0 \times 10^{6}, 4.2 \times 10^{6}, 2.1 \times 10^{6}$ and $1.2 \times 10^{3} \mathrm{~J} \mathrm{~m}^{-3}{ }^{\circ} \mathrm{C}^{-1}$, respectively (Huang, 2000). The weight is the relative volumetric fraction of each constituent ( $\left.\theta_{l, \text { OM }}, \theta_{l, \text { Min }}, \theta_{l, \text { Water }}, \theta_{l, \text { Ice }}, \theta_{l, \text { Air }}\right)$ in the soil. The dynamic thermal conductivity $\left(k_{l}, \mathrm{~W} \mathrm{~m}^{-1}{ }^{\circ} \mathrm{C}^{-1}\right)$ is calculated using the thermal conductivities of the five constituents (Eqs. 6$13)$, with values of $0.25\left(k_{l, \mathrm{OM}}\right), 2.9\left(k_{l, \mathrm{Min}}\right), 0.57\left(k_{l, \text { Water }}\right)$, $2.2\left(k_{l, \text { Ice }}\right)$ and $0.025\left(k_{l, \text { Air }}\right) \mathrm{W} \mathrm{m}^{-1}{ }^{\circ} \mathrm{C}^{-1}$ for organic matter, minerals, water, ice and air, respectively (Johansen, 1975). $\mathrm{ST}_{l}$ denotes the soil temperature of layer $l\left({ }^{\circ} \mathrm{C}\right)$. The upper and lower boundary conditions of the thermal dynamics were determined by the surface energy balance and the defined geothermal heat flux at a soil depth of $35 \mathrm{~m}$.

$$
\begin{aligned}
& C \frac{\partial T}{\partial t}=\frac{\partial}{\partial Z}\left(k \frac{\partial T}{\partial Z}\right)+S \\
& C_{l} \frac{\Delta T_{l}}{\Delta t}=\frac{G_{l-1, l}-G_{l, l+1}}{D_{l}}+S_{l} \\
& G_{l-1, l}=\frac{\left(0.5 k_{l}+0.5 k_{l-1}\right)\left(T_{l-1}-T_{l}\right)}{0.5 D_{l-1}+0.5 D_{l}} \\
& G_{l, l+1}=\frac{\left(0.5 k_{l}+0.5 k_{l+1}\right)\left(T_{l}-T_{l-1}\right)}{0.5 D_{l}+0.5 D_{l+1}} \\
& C_{l}=C_{l, \mathrm{OM}} \theta_{l, \mathrm{OM}}+C_{l, \mathrm{Min}} \theta_{l, \text { Min }}+C_{l, \text { Water }} \theta_{l, \text { Water }} \\
& +C_{l, \text { Ice }} \theta_{l, \text { Ice }}+C_{l, \text { Air }} \theta_{l, \text { Air }} \\
& \theta_{l, \text { Water }} k_{l, \text { Water }}+F_{l, \text { Air }} \theta_{l, \text { Air }} k_{l, \text { Air_adj }} \\
& +F_{l, \mathrm{OM}+\mathrm{Min}}\left(\theta_{l, \mathrm{OM}}+\theta_{l, \mathrm{Min}}\right) k_{l, \mathrm{OM}+\mathrm{Min}} \\
& k_{l}=\frac{+F_{l, \text { Ice }} \theta_{l, \text { Ice }} k_{l, \text { Ice }}}{\theta_{l, \text { Water }}+F_{l, \text { Air }} \theta_{l, \text { Air }}+F_{l, \text { OM }+ \text { Min }}\left(\theta_{l, \text { OM }}+\theta_{l, \text { Min }}\right)} \\
& +F_{l, \text { Ice }} \theta_{l, \text { Ice }} \\
& k_{l, \text { Air_adj }}=\left\{\begin{array}{c}
k_{l, \text { Air }}+0.0238 e^{0.0536 S T_{l}} \\
\left(\theta_{l, \text { Water }}>0.09\right) \\
0.418 \times\left(0.0615+1.96 \theta_{l, \text { Water }}\right) \\
\left(\theta_{l, \text { Water }} \leq 0.09\right)
\end{array}\right. \\
& g_{-} a= \begin{cases}0.333-\frac{0.298 \theta_{l, \text { Air }}}{1-\theta_{l, \text { OM }}-\theta_{l, \text { Min }}} & \left(\theta_{l, \text { Water }}>0.09\right) \\
0.013+0.944 \theta_{l, \text { Water }} & \left(\theta_{l, \text { Water }} \leq 0.09\right)\end{cases} \\
& g_{\_} c=1.0-2.0 g_{\_} a \\
& k_{l, \mathrm{OM}+\mathrm{Min}}=k_{l, \mathrm{OM}}^{\frac{\theta_{l, \mathrm{OM}}}{\theta_{l, \mathrm{OM}}^{+\theta_{l, \mathrm{Min}}}}}+k_{l, \mathrm{Min}}^{\frac{\theta_{l, \mathrm{Min}}}{\theta_{l, \mathrm{OM}}^{+\theta_{l, \mathrm{Min}}}}} \\
& F_{l, \text { Air }}=0.333\left(\frac{2.0}{1.0+g \_a\left(\frac{k_{l, \text { Air_adj }}}{k_{l, \text { Water }}}-1.0\right)}\right. \\
& \left.+\frac{1.0}{1.0+g_{-} c\left(\frac{k_{l, \text { Airadj }}}{k_{l, \text { Water }}}-1.0\right)}\right) \\
& F_{l, \text { OM }+ \text { Min }}=0.333\left(\frac{2.0}{1.0+0.125\left(\frac{k_{l, \text { OM }+ \text { Min }}}{k_{l, \text { Water }}}-1.0\right)}\right. \\
& \left.+\frac{1.0}{1.0+0.75\left(\frac{k_{l, \mathrm{OM}+\mathrm{Min}}}{k_{l, \text { Water }}}-1.0\right)}\right) \\
& F_{l, \text { Ice }}=0.333\left(\frac{2.0}{1.0+0.125\left(\frac{k_{l, \text { Ice }}}{k_{l, \text { Water }}}-1.0\right)}\right. \\
& \left.+\frac{1.0}{1.0+0.75\left(\frac{k_{l, \text { Ice }}}{k_{l, \text { Water }}}-1.0\right)}\right)
\end{aligned}
$$


Compared to the original thermal module, the internal heat exchange due to freezing or thawing $(S)$ was included with an improved algorithm for thermal conductivity $(k)$. In addition, the one-dimensional heat conduction equation (Eq. 1) was solved by converting it to an explicit form in the modified model (Eqs. 2-4), which was solved with the implicit method in the original models (Table S1). The modified CNMMDNDC was able to simulate the thermal dynamics in seasonally frozen regions as well as their impacts on biogeochemical processes, such as the emissions of nitrogen and carbon gases.

\subsection{Catchment and field descriptions}

The study area is the Rierlangshan catchment $\left(34^{\circ} 02^{\prime} \mathrm{N}\right.$, $102^{\circ} 43^{\prime} \mathrm{E}$ ) on the eastern Tibetan Plateau with an area of 189 ha (Yao et al., 2019). This catchment is located in the source region of the Pai-lung River, which is a sub-branch of the upper Yangtze (H. Zhang et al., 2018, 2019). This region is subject to a cold humid continental monsoon climate, and it had an annual mean air temperature of $1.6 \pm 0.7^{\circ} \mathrm{C}$ and average annual precipitation of $649 \pm 94 \mathrm{~mm}$ in 1980-2012 as observed at the Zoige meteorological station $(\sim 80 \mathrm{~km}$ south of the catchment) (Ma et al., 2018). The catchment consists of alpine wetlands, meadows and forests (Yao et al., 2019). The alpine wetlands in the catchment are part of the Zoige wetland and are degraded due to anthropogenic drainage and climate warming (Dong et al., 2010; Li et al., 2014). Degraded alpine wetlands are commonly distributed throughout the Zoige wetland, and nearly $83 \%$ of the permanently inundated wetlands have been converted into "wet grassland" (Xiang et al., 2009; Li et al., 2014).

$\mathrm{CH}_{4}$ and $\mathrm{N}_{2} \mathrm{O}$ fluxes were manually measured once or twice per week using the gas-chromatograph-based static opaque chamber method (H. Zhang et al., 2018) at three sites in alpine wetlands $\left(34^{\circ} 02^{\prime} 6.53^{\prime \prime} \mathrm{N}, 102^{\circ} 43^{\prime} 29.66^{\prime \prime} \mathrm{E}\right.$; $3304 \mathrm{~m}$ a.s.1. $)$ meadows $\left(34^{\circ} 02^{\prime} 01^{\prime \prime} \mathrm{N}, 102^{\circ} 43^{\prime} 28^{\prime \prime} \mathrm{E}\right.$; $3326 \mathrm{~m}$ a.s.1.) and forests $\left(34^{\circ} 01^{\prime} 47.13^{\prime \prime} \mathrm{N}, 102^{\circ} 44^{\prime} 0.87^{\prime \prime} \mathrm{E}\right.$; $3415 \mathrm{~m}$ a.s.1.) in the Rierlangshan catchment from 2013 to 2015 (H. Zhang et al., 2018; Yao et al., 2019; Zhang et al., 2019) (Fig. S1). Each chamber was wrapped with a layer of styrofoam and aluminum foil to mitigate temperature increases inside the enclosures due to the heating of solar radiation. The alpine wetland site is located at a slope base with a slope of $2^{\circ}$. The wetland has suffered from anthropogenic drainage and climate warming and thus has degraded to be seasonally inundated. The alpine meadow site neighbors the alpine wetland site, which is located on the north-facing slope with gradient of $11^{\circ}$. In addition, soil temperatures at different depths and topsoil moisture in the alpine wetlands, meadows and forests were observed daily and twice per week, respectively. The details regarding the available field observations of the $\mathrm{CH}_{4}$ and $\mathrm{N}_{2} \mathrm{O}$ fluxes and the relevant auxiliary variables are described in Table S2.

\subsection{Model simulation}

The modified CNMM-DNDC was applied in the Rierlangshan catchment with the three alpine ecosystems: wetlands, meadows and forests. The dataset required for the catchment simulation included (1) a digital elevation model (DEM) with a resolution of $30 \times 30 \mathrm{~m}^{2}$ from the geospatial data cloud (Fig. S1; http://www.gscloud.cn/, last access: 20 December 2019); (2) a map of alpine ecosystems, including wetlands, meadows and forests; (3) a climate dataset of $3 \mathrm{~h}$ weather data (air temperature, precipitation, wind speed, solar radiation, longwave radiation and humidity), which were obtained from the meteorological station in the target catchment for the years with field observations (November 2013 October 2015) and were adapted from the daily data at the Zoige meteorological station (provided by the National Meteorological Information Center; http://data.cma.cn/, last access: 10 June 2020) for other years; (4) a soil properties dataset of the observed clay fraction, organic matter content, total nitrogen, $\mathrm{pH}$ and bulk density of the three alpine ecosystems in a $1 \mathrm{~m}$ soil profile (Ma et al., 2018; H. Zhang et al., 2018; Yao et al., 2019; Zhang et al., 2019; Table S3); and (5) a management practices dataset including grazing time and intensity for the alpine wetlands and meadows (Table S3). In addition, other required soil inputs of field capacity, wilting point and saturated hydrological conductivity were calculated by pedo-transfer functions (Li et al., 2019; Table S4). The simulated soil depth was defined as $35 \mathrm{~m}$ due to the lower boundary conditions of the thermal dynamics, which were set as the geothermal heat flux at a soil depth of $35 \mathrm{~m}$. The simulated soil profile $(0-35 \mathrm{~m}$ depth) was divided into 23 layers, including the soil $(0-1.5 \mathrm{~m})$ and bedrock $(1.5-35 \mathrm{~m})$. The layer thicknesses of the soil $(0-1.5 \mathrm{~m})$ were $0.01,0.05,0.1$ and $0.5 \mathrm{~cm}$ for the depths of $0-0.1,0.1-0.2$, $0.2-1$ and $1-1.5 \mathrm{~m}$, respectively. The layer thicknesses of the bedrock $(1.5-35 \mathrm{~m})$ were 3.5 and $31 \mathrm{~m}$ for the depths of 1.5 4.0 and $4.0-35 \mathrm{~m}$, respectively. The geothermal heat flux in the catchment was estimated at $0.053 \mathrm{~W} \mathrm{~m}^{-2}$ (Pollack and Chapman, 1977). For the target catchment, the soil water dynamics of the alpine ecosystems were determined by the precipitation, evapotranspiration, infiltration, penetration and lateral flow. Using the database, a catchment simulation of hydro-biogeochemical processes was performed with spatial and temporal resolutions of $30 \times 30 \mathrm{~m}^{2}$ and $3 \mathrm{~h}$, respectively, by the modified CNMM-DNDC from 2012 to 2015, which could reflect the influences of hydrological processes on soil water dynamics. Thus, the soil water dynamics of the seasonally inundated wetlands were determined by the hydrological processes without any artificial disturbances in the catchment simulation.

\subsection{Statistics and analysis}

The statistical criteria applied for evaluating the model performance in this study included (i) the index of agreement 


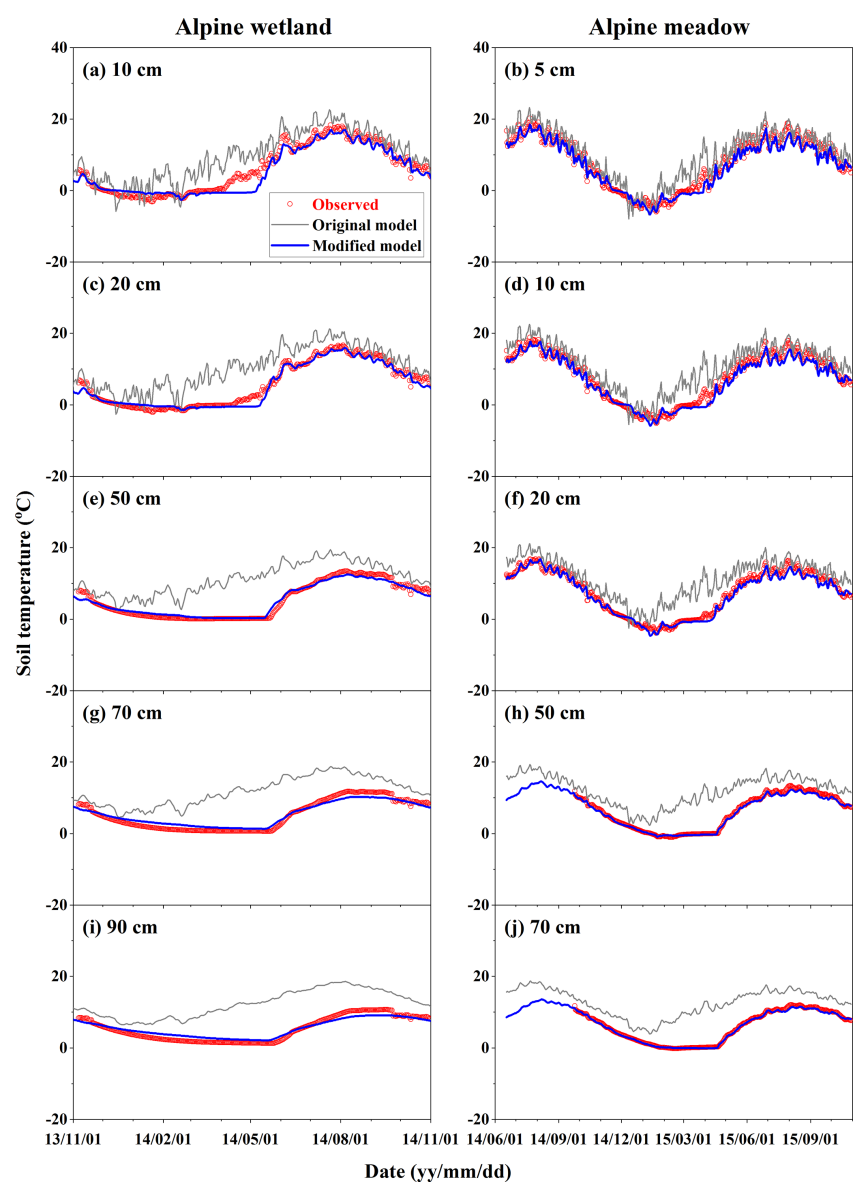

Figure 1. Observed and simulated daily profile soil temperature from the alpine wetlands and meadows by the original and modified models. The legend in panel (a) applies for all panels.

(IA), (ii) the Nash-Sutcliffe efficiency (NSE), and (iii) the determination coefficient $\left(R^{2}\right)$ and slope of the zero-intercept univariate linear regression (ZIR) of the observations against the simulations (e.g., Nash and Sutcliffe, 1970; Willmott and Matsuura, 2005; Moriasi et al., 2007; Congreves et al., 2016; Jiang, 2010; Dubache et al., 2019). A value of the IA (01) closer to 1 showed a better simulation. An NSE value (ranging from minus infinity to 1) closer to 1 was better. Better model performance was indicated by a slope and an $R^{2}$ value that were both closer to 1 in a significant ZIR. The significance level of the ZIR was indicated by the $P$ value. For more details on these criteria, refer to the Eqs. (S1)(S4) in Table S5. In addition, the SPSS Statistics Client 19.0 (SPSS Inc., Chicago, IL, USA) and Origin 8.0 (OriginLab, Northampton, MA, USA) software packages were applied for the statistical analysis and graphical comparison.

\section{Results}

\subsection{Model validation}

\subsubsection{Soil temperature and moisture}

The profile soil temperatures were observed for alpine wetland and meadow, but only topsoil temperature, which could be used for model validation, was observed for the alpine forest. The simulated soil temperatures of the three typical alpine ecosystems were significantly improved by including the scientific processes of soil thermal dynamics suitable for seasonally frozen regions (Figs. 1 and S2). The simulated seasonal dynamics and magnitudes were consistent with those from the field observations for various soil depths, with IA, NSE, and ZIR slopes and $R^{2}$ values of $0.91-$ $1.00,0.68-0.99,0.83-1.09$ and $0.73-1.00$ for the three alpine ecosystems, respectively (Table 1). For the observed alpine wetlands and meadows, the simulation showed that the freezing of soil started in early November and continued to the end of April in the next year. The frozen depth reached a maximum in the middle of February. However, the simulated maximum frozen depths for the observed alpine meadows (0.69$0.74 \mathrm{~m}$ ) were approximately double those for the alpine wetlands (0.30-0.39 m) (Fig. S3).

For the soil moisture, only topsoil moisture, which could be applied for model validation, was observed in the three alpine ecosystems. The simulated topsoil moisture dynamics were comparable to those from the field observations, with IA and NSE values of 0.49 to 0.83 and -0.80 to 0.32 for the three alpine ecosystems, respectively (Fig. 2 and Table 1). In comparison to the other alpine ecosystems, the alpine wetlands had higher soil moisture, which ranged from 0.41 to 0.98 and from 0.38 to 0.93 for the observations and simulations in the water-filled pore space (WFPS), respectively. The soil moisture values of the alpine meadows and forests were highly variable and depended on the variation trend in precipitation for both observations and simulations. However, an underestimation of soil moisture in the winter period occurred for both alpine meadows and forests due to a possible overestimation of evapotranspiration. The performances of the modified model in simulating the soil profile temperature and topsoil moisture indicate that the modified CNMMDNDC can generally predict the soil thermal and topsoil moisture dynamics in the three alpine ecosystems, which is crucial for correctly simulating soil hydrology, plant growth and biogeochemical processes.

\subsubsection{Methane fluxes}

The daily observed $\mathrm{CH}_{4}$ emissions from the alpine wetlands were highly variable and showed a clear seasonal cycle, with intensive $\mathrm{CH}_{4}$ emissions from May to November and weak emissions in other periods (Fig. 3a). The observed alpine meadows and forests functioned exclusively as sinks 
Table 1. Statistics of the validated variables by the original and modified CNMM-DNDC for three typical alpine ecosystems.

\begin{tabular}{|c|c|c|c|c|c|c|c|c|c|c|c|c|c|}
\hline \multirow[t]{2}{*}{ Item } & \multirow[t]{2}{*}{ Ecosystem } & \multirow[t]{2}{*}{$n^{\mathrm{a}}$} & \multirow[t]{2}{*}{$\mathrm{DR}^{\mathrm{b}}$} & \multicolumn{2}{|c|}{ IA } & \multicolumn{2}{|c|}{ NSE } & \multicolumn{2}{|c|}{ ZIR slope } & \multicolumn{2}{|c|}{$\operatorname{ZIR} R^{2^{\mathrm{e}}}$} & \multicolumn{2}{|c|}{ ZIR $P$} \\
\hline & & & & $\mathrm{O}^{\mathrm{c}}$ & $\mathrm{M}^{\mathrm{d}}$ & $\mathrm{O}$ & M & $\mathrm{O}$ & M & $\mathrm{O}$ & M & $\mathrm{O}$ & M \\
\hline \multicolumn{14}{|l|}{ Soil temperature } \\
\hline \multirow[t]{2}{*}{$5 \mathrm{~cm}$} & Meadow & 500 & Daily & 0.90 & $0.96^{f}$ & 0.82 & 0.95 & 0.84 & 1.09 & 0.89 & 0.96 & $<0.001$ & $<0.001$ \\
\hline & Forest & 48 & Daily & 0.85 & 0.91 & 0.37 & 0.68 & 0.64 & 0.83 & 0.68 & 0.73 & $<0.001$ & $<0.001$ \\
\hline \multirow[t]{2}{*}{$10 \mathrm{~cm}$} & Wetland & 366 & Daily & 0.90 & 0.98 & 0.57 & 0.92 & 0.72 & 1.07 & 0.81 & 0.93 & $<0.001$ & $<0.001$ \\
\hline & Meadow & 500 & Daily & 0.93 & 0.99 & 0.71 & 0.95 & 0.80 & 1.08 & 0.85 & 0.96 & $<0.001$ & $<0.001$ \\
\hline \multirow[t]{2}{*}{$20 \mathrm{~cm}$} & Wetland & 366 & Daily & 0.82 & 0.99 & 0.18 & 0.96 & 0.64 & 1.05 & 0.66 & 0.97 & $<0.001$ & $<0.001$ \\
\hline & Meadow & 500 & Daily & 0.87 & 0.99 & 0.48 & 0.97 & 0.74 & 1.06 & 0.76 & 0.98 & $<0.001$ & $<0.001$ \\
\hline \multirow[t]{2}{*}{$50 \mathrm{~cm}$} & Wetland & 366 & Daily & 0.66 & 0.99 & -1.01 & 0.97 & 0.51 & 1.05 & 0.43 & 0.97 & $<0.001$ & $<0.001$ \\
\hline & Meadow & 401 & Daily & 0.70 & 1.00 & -0.48 & 0.99 & 0.58 & 1.06 & 0.53 & 1.00 & $<0.001$ & $<0.001$ \\
\hline \multirow[t]{2}{*}{$70 \mathrm{~cm}$} & Wetland & 366 & Daily & 0.58 & 0.98 & -2.23 & 0.93 & 0.47 & 1.05 & 0.38 & 0.93 & $<0.001$ & $<0.001$ \\
\hline & Meadow & 401 & Daily & 0.64 & 1.00 & -1.19 & 0.99 & 0.54 & 1.03 & 0.49 & 1.00 & $<0.001$ & $<0.001$ \\
\hline $90 \mathrm{~cm}$ & Wetland & 366 & Daily & 0.52 & 0.98 & -4.07 & 0.90 & 0.44 & 1.03 & 0.36 & 0.90 & $<0.001$ & $<0.001$ \\
\hline \multirow[t]{3}{*}{ Soil moisture } & Wetland & 74 & Daily & 0.63 & 0.83 & -1.65 & 0.20 & 1.31 & 1.13 & - & 0.60 & - & $<0.001$ \\
\hline & Meadow & 128 & Daily & 0.78 & 0.78 & 0.28 & 0.32 & 0.96 & 0.93 & 0.30 & 0.41 & $<0.001$ & $<0.001$ \\
\hline & Forest & 40 & Daily & 0.48 & 0.49 & -1.04 & $-\mathbf{0 . 8 0}$ & 1.21 & 1.19 & - & - & - & - \\
\hline \multirow[t]{3}{*}{ Daily $\mathrm{CH}_{4}$ flux } & Wetland & 180 & Daily & 0.37 & 0.74 & -11.1 & -0.73 & 0.46 & 0.87 & - & - & - & - \\
\hline & Meadow & 168 & Daily & 0.87 & 0.88 & 0.42 & 0.38 & 1.09 & 0.94 & 0.44 & 0.39 & $<0.001$ & $<0.001$ \\
\hline & Forest & 49 & Daily & 0.59 & 0.57 & -2.79 & -3.39 & 0.92 & 0.79 & - & - & - & - \\
\hline \multirow[t]{3}{*}{ Daily $\mathrm{N}_{2} \mathrm{O}$ flux } & Wetland & 180 & Daily & 0.01 & 0.26 & -323 & -0.07 & 0.01 & 0.59 & - & - & - & - \\
\hline & Meadow & 168 & Daily & 0.23 & 0.44 & -0.16 & -1.76 & 0.99 & 0.35 & - & - & - & - \\
\hline & Forest & 58 & Daily & 0.47 & 0.47 & -1.85 & -1.64 & 0.44 & 0.47 & - & - & - & - \\
\hline
\end{tabular}

${ }^{\mathrm{a}} n$ indicates the number of the observations. ${ }^{\mathrm{b}} \mathrm{DR}$ denotes the time resolution of the observed data. ${ }^{\mathrm{c}} \mathrm{O}$ indicates the simulations by the original model. ${ }^{\mathrm{d}} \mathrm{M}$ indicates the simulations by the modified model. ${ }^{\mathrm{e}}$ "-_" indicates no value due to the sum of the regression square being larger than the sum of the total square for the regression. ${ }^{\mathrm{f}}$ The bold statistical values indicate better model performances. IA, NSE, ZIR slope, ZIR $R^{2}$ and ZIR $P$ indicate the index of agreement, Nash-Sutcliffe efficiency, determination coefficient and slope of the zero-intercept univariate linear regression (ZIR) of the observations against the simulations, and significance level of the ZIR.

of atmospheric $\mathrm{CH}_{4}$ with higher rates of uptake during the growing season and lower uptake rates in the dormant season (Fig. 3b, c). The original model significantly overestimated $\mathrm{CH}_{4}$ emissions from the alpine wetlands. The modified CNMM-DNDC accurately identified the functions of the sources or sinks in the three alpine ecosystems and generally captured the magnitude and seasonal characteristics of the daily $\mathrm{CH}_{4}$ fluxes, with an IA of $0.57-0.88$ for the three alpine ecosystems (Fig. 3a-c and Table 1). However, the $\mathrm{CH}_{4}$ uptake rates during the dormant season were obviously underestimated by the modified model at both sites, especially at the alpine forest site, which was responsible for the underestimation of cumulative $\mathrm{CH}_{4}$ uptake. The observed cumulative $\mathrm{CH}_{4}$ emissions ranged from -2.60 to $33.5 \mathrm{~kg} \mathrm{Cha}^{-1} \mathrm{yr}^{-1}$, and the modeled values ranged from -1.90 to $31.0 \mathrm{~kg} \mathrm{Cha}^{-1} \mathrm{yr}^{-1}$ (Fig. 4a). These results indicate that the modified CNMM-DNDC well simulated the $\mathrm{CH}_{4}$ fluxes of the three typical alpine ecosystems.

\subsubsection{Nitrous oxide fluxes}

The daily observed $\mathrm{N}_{2} \mathrm{O}$ emissions from the alpine wetlands were higher than those from the alpine meadows but lower than those from the alpine forests (Fig. 3d-f). Similar seasonal patterns of $\mathrm{N}_{2} \mathrm{O}$ fluxes were observed for the three alpine ecosystems with intensive emissions in the growing season. The $\mathrm{N}_{2} \mathrm{O}$ emission peak during the dormant season was observed in the alpine meadows, which was the major contributor to annual emissions. The modified CNMMDNDC generally captured the seasonal dynamics of daily $\mathrm{N}_{2} \mathrm{O}$ fluxes with an IA of $0.26-0.47$ for the three alpine ecosystems (Fig. 3d-f and Table 1), but the $\mathrm{N}_{2} \mathrm{O}$ emissions from the alpine wetlands were significantly overestimated by the original model. For the modified model, the simulated $\mathrm{N}_{2} \mathrm{O}$ emissions from the alpine wetlands and forests showed obvious seasonal patterns with higher emissions during the growing season, but no abrupt emission peak was captured at the end of the growing season for the alpine wetlands. In addition, compared with the original model, the modified model captured the peak emissions that occurred during the 


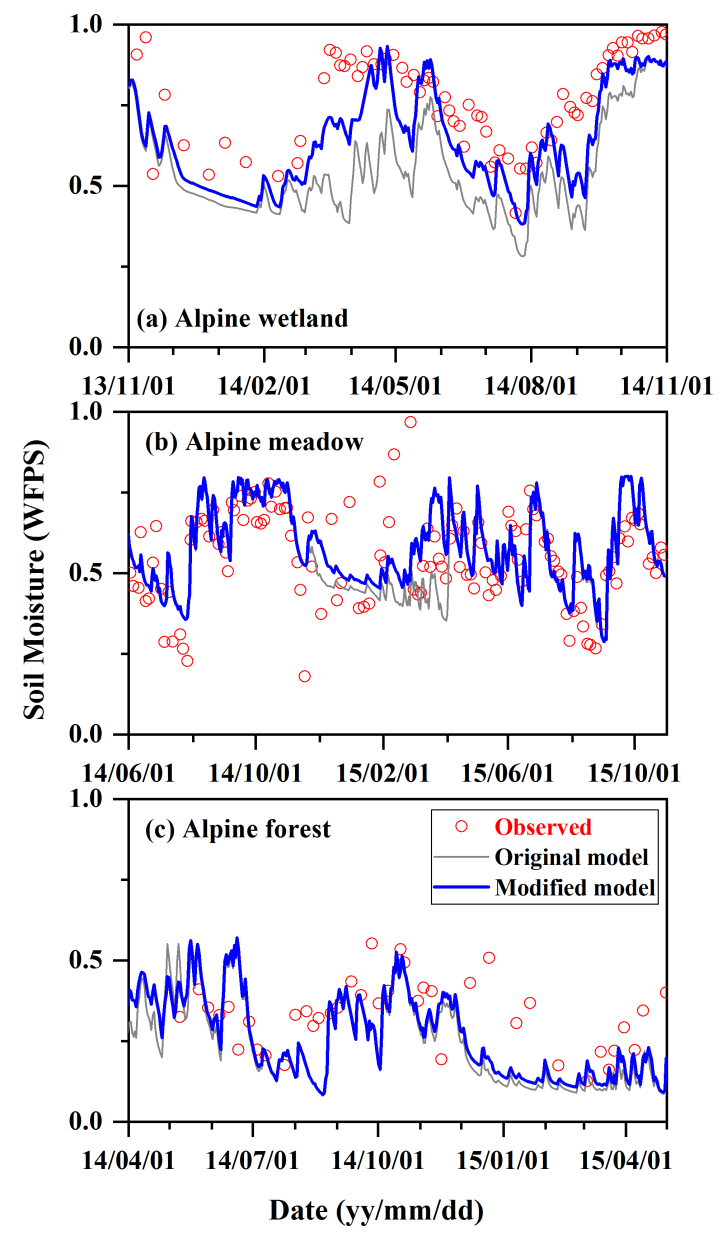

Figure 2. Observed and simulated daily topsoil $(0-6 \mathrm{~cm})$ moisture in the water-filled pore space (WFPS) from the alpine wetlands, meadows and forests by the original and modified models. The legend in panel (c) applies for all panels.

freeze-thaw period from the alpine meadows due to the death of microbes, but the dynamics of the peak emissions were not well simulated. The observed cumulative $\mathrm{N}_{2} \mathrm{O}$ emissions ranged from 0.14 to $0.58 \mathrm{~kg} \mathrm{Nha}^{-1} \mathrm{yr}^{-1}$, and the modeled values ranged from 0.12 to $0.32 \mathrm{~kg} \mathrm{Nha}^{-1} \mathrm{yr}^{-1}$ (Fig. 4b). These results indicate that the modified CNMM-DNDC has the potential to estimate $\mathrm{N}_{2} \mathrm{O}$ emissions in seasonally frozen regions.

\subsection{Annual aggregate emissions of $\mathrm{CH}_{4}$ and $\mathrm{N}_{2} \mathrm{O}$}

Annual aggregate emissions of $\mathrm{CH}_{4}$ and $\mathrm{N}_{2} \mathrm{O}$ in carbon dioxide $\left(\mathrm{CO}_{2}\right)$ equivalents were calculated for the three alpine ecosystems from November 2013 to November 2014 for alpine wetlands and meadows and from April 2014 to April 2015 for alpine forests, and the global warming potentials were 34 for $\mathrm{CH}_{4}$ and 298 for $\mathrm{N}_{2} \mathrm{O}$ on a 100-year time horizon (IPCC, 2013). The simulated aggregate emissions by the modified model were $1.5,0.015$ and $0.061 \mathrm{Mg} \mathrm{CO}_{2} \mathrm{eq} \mathrm{ha}^{-1} \mathrm{yr}^{-1}$ for the observed alpine wetlands, meadows and forests, respectively, which were consistent with those from the field observations (1.6, 0.014, and $0.15 \mathrm{Mg} \mathrm{CO}_{2} \mathrm{eq} \mathrm{ha}^{-1} \mathrm{yr}^{-1}$ for the alpine wetlands, meadows and forests, respectively) (Fig. 4c). However, the original model significantly overestimated the aggregate emissions due to the high predicted $\mathrm{CH}_{4}$ and $\mathrm{N}_{2} \mathrm{O}$ emissions. In comparison, the observed seasonally inundated wetlands functioned as the sources of aggregate emissions of $\mathrm{CH}_{4}$ and $\mathrm{N}_{2} \mathrm{O}$, but the aggregate emissions from adjacent wet alpine meadows were much lower.

\section{Discussions}

\subsection{Model performance in simulating thermal dynamics}

The soil freeze-thaw cycles in seasonally frozen regions determine the soil profile temperature and hydrological processes, which are key factors that regulate the cycling of nitrogen and carbon (e.g., Zhang et al., 2015; Hugelius et al., 2020). Therefore, improving the scientific processes of soil thermal dynamics in the presence of active layer dynamics is essential for applying the CNMM-DNDC to simulate the biogeochemical processes in seasonally frozen regions, which are sensitive and vulnerable to climate change and anthropogenic activities (Hatano, 2019; Hugelius et al., 2020; Jiang et al., 2020). The original model adopted a relatively simple module to calculate thermal transportation within the soil profile and did not consider the effects of freeze-thaw cycles on soil temperature and moisture. The newly incorporated module was based on explicit energy conservation and exchange in the soil profile and successfully captured the variations in soil temperature and topsoil moisture for the three alpine ecosystems during the freeze-thaw period. The simulated lower soil frozen depth for the observed alpine wetland was primarily attributed to the higher soil profile moisture level, as the thermal conductivity and heat capacity for waterfilled pores were higher than those for air-filled pores. In order to quantify the impacts of climate change on the cycling of carbon and water on the regional and global scales, several large-scale ecosystem models or macroscale hydrological models, such as the Terrestrial Ecosystem Model, LundPotsdam-Jena dynamic global vegetation model and Variable Infiltration Capacity model, have been enhanced to simulate the soil thermal dynamics at high northern latitudes (e.g., Wania et al., 2009; Zhuang et al., 2001; Cuo et al., 2015; Jiang et al., 2020). In addition, the soil thermal modules have also been improved in some biogeochemical models, such as DNDC and Mobile-DNDC, to evaluate the influences of climate warming on the biogeochemical processes in highlatitude regions (e.g., Zhang et al., 2003; de Bruijn et al., 2009; Wolf et al., 2011; Zhang et al., 2012; Deng et al., 2014). Compared with the simulated soil profile tempera- 

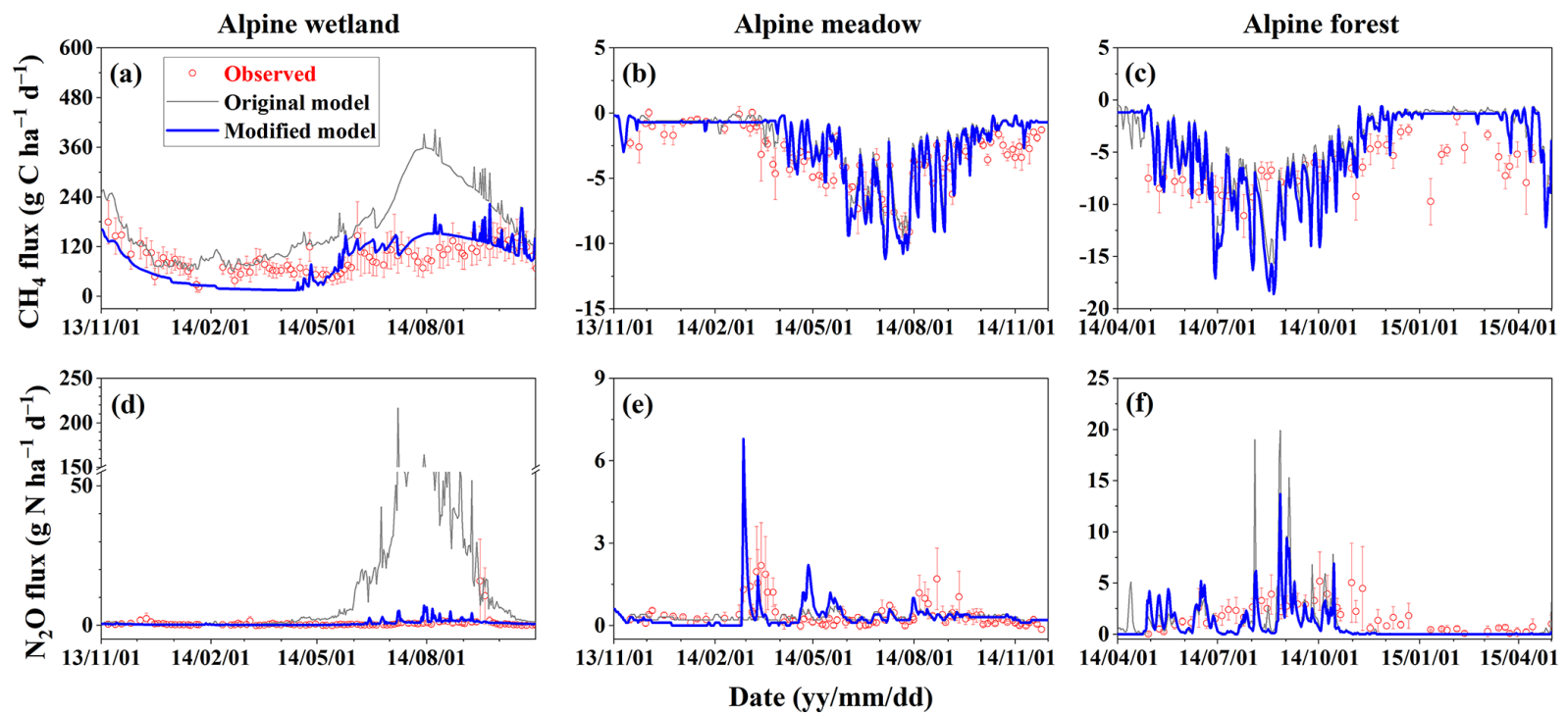

Figure 3. Observed and simulated daily methane $\left(\mathrm{CH}_{4}\right)$ and nitrous oxide $\left(\mathrm{N}_{2} \mathrm{O}\right)$ fluxes from the alpine wetlands, meadows and forests by the original and modified models. The vertical bar for each observation indicates the standard error of six spatial replicates. The legend in panel (a) applies for all panels.

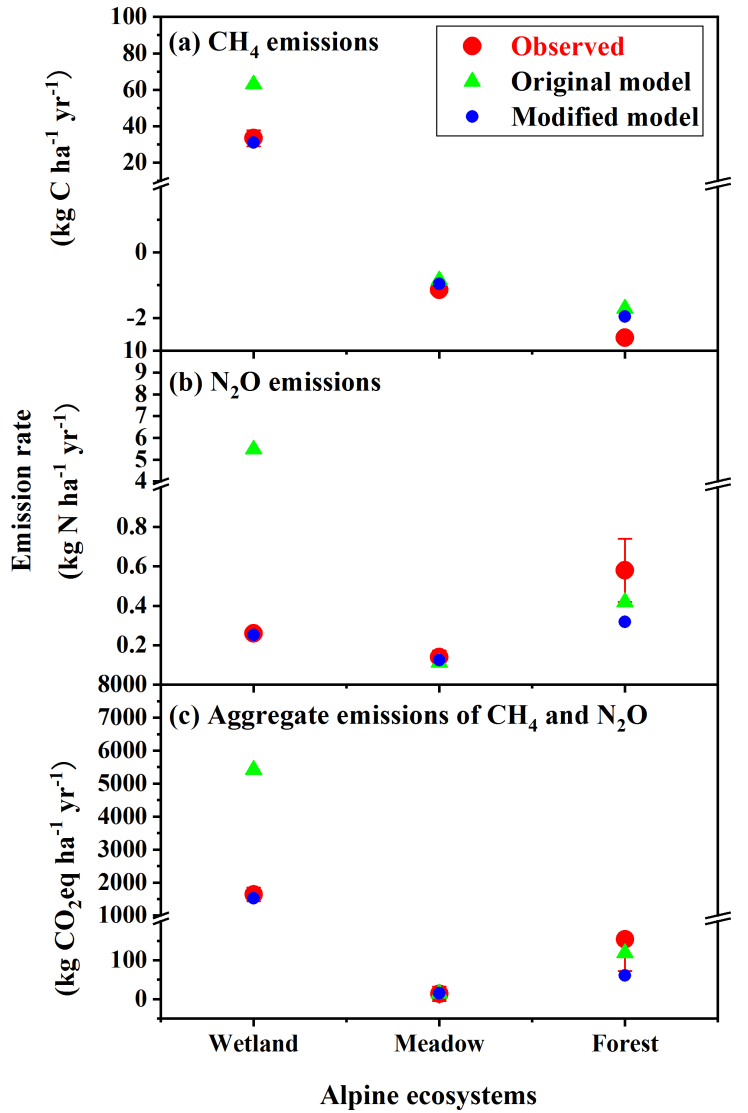

Figure 4. Observed and simulated annual emissions of methane $\left(\mathrm{CH}_{4}\right)$, nitrous oxide $\left(\mathrm{N}_{2} \mathrm{O}\right)$ and aggregate emissions of both from the alpine wetlands (Wetland), meadows (Meadow) and forests (Forest). The legend in panel (a) applies for all panels. tures by the models at different scales, the simulations in this study by the modified CNMM-DNDC were equally good, especially for deeper soil layers (e.g., Wania et al., 2009). For the validated topsoil moisture in this study, the modified model generally captured the variation trends, which were comparable with the performances of other models (e.g., de Bruijn et al., 2009; Wolf et al., 2011; Cuo et al., 2015). However, compared with the studies focused on simulating soil moisture (e.g., Ford et al., 2014), further improvements are still required to improve the model performance in simulating the soil moisture. These results indicate the efficiency of the incorporated module in simulating soil thermal and topsoil moisture dynamics in seasonally frozen regions.

\subsection{Model performance in simulating $\mathrm{CH}_{4}$ fluxes}

Compared with the annually inundated wetlands, the seasonally inundated wetlands had relatively low observed and simulated $\mathrm{CH}_{4}$ emissions due to the significant influences of the water table level on $\mathrm{CH}_{4}$ emissions (e.g., Hatano, 2019; Zhang et al., 2019). The $\mathrm{CH}_{4}$ emissions simulated by the CNMM-DNDC were determined by the processes of production, oxidation and transpiration. The unsaturated soil with moisture levels ranging from 0.41 to 0.98 in the WFPS resulted in a small $\mathrm{CH}_{4}$ balloon and thus reduced $\mathrm{CH}_{4}$ production. At the same time, relatively dry conditions caused the upper soil layer to act as an efficient oxidative methanotrophic barrier for the diffusion of $\mathrm{CH}_{4}$ from the subsoil and thus decreased $\mathrm{CH}_{4}$ emissions (Kandel et al., 2018; Tan et al., 2020). In addition, the highly fluctuating $\mathrm{CH}_{4}$ emissions simulated by the modified model were also attributed to the high dependency of $\mathrm{CH}_{4}$ production on soil moisture, 
which controlled the size of the $\mathrm{CH}_{4}$ balloon. Theoretically, the $\mathrm{CH}_{4}$ emissions simulated by the original model should not be higher than those simulated by the modified model due to the lower predicted soil moisture level. The overestimated $\mathrm{CH}_{4}$ emissions simulated by the original model were mainly attributed to the overestimated soil temperature due to their influences on mineralized substrates for $\mathrm{CH}_{4}$ production, as well as on the processes of $\mathrm{CH}_{4}$ production. This result implies that global warming may trigger intensive $\mathrm{CH}_{4}$ emissions from degraded wetlands, which could partly serve as a trade-off for the decreased $\mathrm{CH}_{4}$ emissions due to the lower water table level in degraded wetlands (e.g., Gong et al., 2020). For the studies focused on simulating $\mathrm{CH}_{4}$ emissions from wetlands by the large-scale ecosystem models, model validation with field observation is difficult due to coarse spatial resolutions (e.g., Zhuang et al., 2004). For the biogeochemical model, such as DNDC, the dynamics of $\mathrm{CH}_{4}$ emissions from wetland and peatland in the northern permafrost regions were well simulated (Zhang et al., 2012; Deng et al., 2014), which showed seasonal variations and magnitudes consistent with those in this study. Both observations and simulations showed that the $\mathrm{CH}_{4}$ uptake in alpine forests was higher than that in alpine meadows, which was mainly attributed to the high SOC content of the alpine forests in the simulation. Methane uptake by upland soils is a biological process governed by the availability of $\mathrm{CH}_{4}$ and oxygen as well as the activity and quantity of methanotrophic bacteria in soils (e.g., Liu et al., 2007; Zhang et al., 2014). In the model, the simulated $\mathrm{CH}_{4}$ uptake was positively related to the SOC content, which is closely related to the population size of methanotrophic bacteria. Thus, the SOC content primarily contributed to the differences in $\mathrm{CH}_{4}$ uptake from alpine meadows and forests, as the values for forests were more than twice those for meadows (Table S3). As the simulated dynamic characteristics of $\mathrm{CH}_{4}$ uptake were primarily regulated by soil temperature and moisture, the inhibitory effects of low soil temperature $\left(<0.0^{\circ} \mathrm{C}\right)$ on $\mathrm{CH}_{4}$ uptake rates resulted in obvious underestimations in the dormant season for both alpine meadows and forests. Therefore, an improved parameterization for simulating $\mathrm{CH}_{4}$ uptake under low soil temperatures is required for the model to better capture the dynamics of $\mathrm{CH}_{4}$ uptake in the dormant season.

\subsection{Model performance in simulating $\mathrm{N}_{2} \mathrm{O}$ fluxes}

In comparison, the $\mathrm{N}_{2} \mathrm{O}$ emissions from the alpine wetlands and forests were higher than those from the alpine meadows for both the observations and the simulations due to the high SOC content and nitrogen availability. Natural wetlands are large carbon reserves and play a crucial role in mitigating global warming (e.g., Deng et al., 2014; Kang et al., 2020; Tan et al., 2020). The intentional drainage of annually inundated wetlands alters not only the water regime but also nutrient availability (e.g., Hoffmann et al., 2016). The relatively low simulated soil moisture for the alpine wetlands stimulated the decomposition of SOC and nitrogen (or peat oxidation) under aerobic conditions, thus improving nitrogen mineralization for nitrification and denitrification and enhancing $\mathrm{N}_{2} \mathrm{O}$ emissions (e.g., Tan et al., 2020; Zhang et al., 2020). The intensive $\mathrm{N}_{2} \mathrm{O}$ emissions simulated by the original model resulted from the overestimated soil temperature for the alpine wetlands. Firstly, as the presence of ice could impede the water movement, the water lateral flows were promoted by the original model due to the neglecting of freeze-thaw cycles. These further resulted in the lower simulated soil moisture as compared with the modified model (Fig. S4), which provided favorable oxygen conditions for $\mathrm{N}_{2} \mathrm{O}$ production. Meanwhile, the simulated high soil moisture by the modified model provided feasible anaerobic conditions for thorough denitrification. Secondly, higher simulated soil temperature by the original model also facilitated mineralization, which provided more available mineral nitrogen. Field studies have shown that high SOC concentrations could stimulate the processes of mineralization and nitrification in forests (e.g., Li et al., 2005; Yao et al., 2019). The model input of soil organic matter measured in the observed alpine forests was more than twice that in the observed alpine meadows (Table S3). Thus, the high SOC content at the alpine forest site provided more available nitrogen through mineralization and thus stimulated the nitrification processes in the simulation. Furthermore, the seasonal grazing that occurred in the alpine meadows resulted in constant loss of available nitrogen and thus hindered the $\mathrm{N}_{2} \mathrm{O}$ emissions from the biological processes in the simulation. Field observations showed that the soil freeze-thaw cycles that occurred in seasonally frozen regions not only increased the availability of nitrogen and carbon substrates by disruption of soil aggregates but also affected the structure, population and activity of the microbes, thus influencing the emissions of $\mathrm{N}_{2} \mathrm{O}$ (e.g., Song et al., 2019). De Bruijn et al. (2009) have explored combined mechanisms for simulating freeze-thawrelated $\mathrm{N}_{2} \mathrm{O}$ emissions, which were the promoted anaerobiosis and denitrification due to reduced gas diffusion derived from soil frost and snow cover and the stimulated microbial growth due to easily decomposable organic carbon and nitrogen derived from the dead microbes during freeze-thaw cycles. Wolf et al. (2011) introduced an impedance factor to parameterize the reduced water flow between layers in the presence of ice, which could capture the freeze-thaw-related $\mathrm{N}_{2} \mathrm{O}$ emissions for ungrazed steppe. In the CNMM-DNDC, threshold values of soil temperature were set to trigger the death of microbes during the freezing period and stimulate the production of $\mathrm{NO}, \mathrm{N}_{2} \mathrm{O}$ and $\mathrm{N}_{2}$ using substrates derived from the dead microbes during the thawing period, which was similar to one of the mechanisms explored by de Bruijn et al. (2009). However, compared with the simulated freezethaw-related $\mathrm{N}_{2} \mathrm{O}$ emissions by other studies, the simulated dynamics of peak emissions due to freeze-thaw cycles in this study were inconsistent with those from the field observations. Thus, improvements are required to incorporate some 
other effective mechanisms to better capture the dynamic characteristics. The peak emissions during the freeze-thaw period were not captured by the original model due to the significantly overestimated soil temperature. The low evaluation statistics for the daily fluxes, especially for the alpine forests, were also attributed to the underestimation of background emissions, which resulted from both measurement errors due to low fluxes around detection limits $\left( \pm 0.41 \mathrm{~g} \mathrm{~N} \mathrm{ha}^{-1} \mathrm{~d}^{-1}\right)$ and model deficiencies in the simulation of tight nitrogen cycling in natural ecosystems.

Compared with the empirical model, one key advantage of the process-oriented models is that the models are independent of the local parameterization (Zhang et al., 2015). In this study, default internal parameter combinations of biogeochemical processes were used for the original and modified models, which have been applied in the catchment simulation in the subtropical region (W. Zhang et al., 2018) due to the limited field observations (only 1 year) for both calibration and validation. The biogeochemical processes were predicted by the first-order and Michaelis-Menten kinetics in the CNMM-DNDC based on some defined parameters of flow fractionation. For instance, there are 17 parameters related to $\mathrm{N}_{2} \mathrm{O}$ emissions in the module of denitrification (Table S6), which would inevitably increase the uncertainty in simulation. Houska et al. (2017) found that hydrobiogeochemical models can be right for the wrong reasons, such as matching greenhouse gas emissions while failing to simulate soil moisture, which emphasizes the importance of simultaneous validations of multiple variables. Thus, simultaneous validations of $\mathrm{CH}_{4}$ and $\mathrm{N}_{2} \mathrm{O}$ fluxes, as well as soil environment variables, are necessary for comprehensive evaluation of the model performance. In addition, microbial ecology was recently recommended to be integrated into the biogeochemical model using a smaller number of well-defined kinetic parameters, such as in MOMOS (Pansu et al., 2010; Treseder et al., 2011). Therefore, direct control of microbes on biogeochemical processes, such as the stoichiometry of the decomposer, is required to be included in the CNMM-DNDC in the near future. The model performances of simulating various variables for three typical alpine ecosystems in the Rierlangshan catchment imply that the modified CNMM-DNDC can be applied to predict the thermal dynamics and fluxes of $\mathrm{CH}_{4}$ and $\mathrm{N}_{2} \mathrm{O}$ from alpine ecosystems in seasonally frozen regions.

\section{Conclusions}

To apply the process-oriented hydro-biogeochemical model Catchment Nutrient Management Model - DeNitrificationDeComposition (CNMM-DNDC) in seasonally frozen regions, an improved module of soil thermal dynamics for describing the soil thermal regime in the presence of freezethaw cycles was incorporated in this study. Using the unique experimental dataset obtained in the Rierlangshan catchment with the typical alpine wetland, meadow and forest ecosystems, the modified model was evaluated for simulating soil thermal dynamics (soil profile temperature), topsoil moisture, and fluxes of methane $\left(\mathrm{CH}_{4}\right)$ and nitrous oxide $\left(\mathrm{N}_{2} \mathrm{O}\right)$ in seasonally frozen regions of the Tibetan Plateau. The modified CNMM-DNDC could generally capture the seasonal dynamics and magnitudes of profile soil temperature, topsoil moisture, and fluxes of $\mathrm{CH}_{4}$ and $\mathrm{N}_{2} \mathrm{O}$ in seasonally frozen regions. Both the observed and the simulated $\mathrm{CH}_{4}$ and $\mathrm{N}_{2} \mathrm{O}$ fluxes from three alpine ecosystems indicate that the aggregate emissions of $\mathrm{CH}_{4}$ and $\mathrm{N}_{2} \mathrm{O}$ were highest for the wetland among the three alpine ecosystems. The intensive aggregate emissions of $\mathrm{CH}_{4}$ and $\mathrm{N}_{2} \mathrm{O}$ were regulated by the high soil moisture, which was primarily determined by the $\mathrm{CH}_{4}$ emissions. This study implies that a hydro-biogeochemical model, such as the modified CNMM-DNDC, is able to predict soil thermal dynamics, topsoil moisture, and fluxes of $\mathrm{CH}_{4}$ and $\mathrm{N}_{2} \mathrm{O}$ in seasonally frozen regions with an improved physically based soil thermal module.

Data availability. The model, input, output and code can be obtained from https://doi.org/10.6084/m9.figshare.14685441 (Zhang et al., 2019, last acess: 28 May 2021). All the observed datasets used in this study are available from the co-authors.

Supplement. The supplement related to this article is available online at: https://doi.org/10.5194/bg-18-4211-2021-supplement.

Author contributions. $\mathrm{XZ}$ and $\mathrm{WZ}$ contributed to developing the idea and enhancing the science of this study. WZ improved the scientific processes of the model, implemented the model simulations and prepared the manuscript with contributions from all co-authors. SL improved the model structure for standard input. ZY, HZ, LM, KW, RW and CL designed and carried out the field experiments. $\mathrm{SH}$ collected and established the input database for modeling. JD and YL contributed to the modification of the model and the improvement of the manuscript.

Competing interests. The authors declare that they have no conflict of interest.

Disclaimer. Publisher's note: Copernicus Publications remains neutral with regard to jurisdictional claims in published maps and institutional affiliations.

Financial support. This research has been supported by the National Key Research and Development Program of China (grant no. 2016YFA0602303), the Chinese Academy of Sciences (grant no. ZDBS-LY-DQC007), the National Key Scientific and Technological Infrastructure project "Earth System Science Numerical Simulator Facility" (EarthLab), the National Natural Science Foundation 
of China (grant no. 41603075), and the China Postdoctoral Science Foundation (grant no. 2019M650808).

Review statement. This paper was edited by Sébastien Fontaine and reviewed by Tobias Houska and Marc Pansu.

\section{References}

Bechmann, M.: Long-term monitoring of nitrogen in surface and subsurface runoff from small agricultural dominated catchments in Norway, Agr. Ecosyst. Environ., 198, 13-24, 2014.

Bosch, N., Allan, J., Dolan, D., Han, H., and Richards, R.: Application of the Soil and Water Assessment Tool for six watersheds of Lake Erie: Model parameterization and calibration, J. Great Lakes Res., 37, 263-271, 2011.

Breuer, L., VachÉ, K., Julich, S., and Frede, H.: Current concepts in nitrogen dynamics for mesoscale catchments, Hydrol. Sci. J., 53, 1059-1074, 2010.

Canfield, D., Glazer, A., and Falkowski, P.: The evolution and future of Earth's nitrogen cycle, Science, 330, 192-196, 2010.

Castellano, M., Lewis, D., and Kaye, J.: Response of soil nitrogen retention to the interactive effects of soil texture, hydrology, and organic matter, J. Geophys. Res.-Biogeo., 118, 280-290, 2013.

Chen, D., Li, Y., Grace, P., and Mosier, A.: $\mathrm{N}_{2} \mathrm{O}$ emissions from agricultural lands: a synthesis of simulation approaches, Plant Soil, 309, 169-189, 2008.

Cheng, K., Ogle, S., Parton, W., and Pan, G.: Simulating greenhouse gas mitigation potentials for Chinese Croplands using the DAYCENT ecosystem model, Glob. Change Biol., 20, 948-962, 2014.

Collatz, G., Ribas-Carbo, M., and Berry, J.: Coupled photosynthesis-stomatal conductance model for leaves of C4 plants, Aust. J. Plant Physiol., 19, 519-538, 1992.

Collins, A., Zhang, Y., Winter, M., Inman, A., Jones, J., Johnes, P., Cleasby, W., Vrain, E., Lovett, A., and Noble, L.: Tackling agricultural diffuse pollution: What might uptake of farmer-preferred measures deliver for emissions to water and air?, Sci. Total Environ., 547, 269-281, 2016.

Congreves, K., Grant, B., Dutta, B., Smith, W., Chantigny, M., Rochette, and Desjardins, R.: Prediction ammonia volatilization after field application of swine slurry: DNDC model development, Agr. Ecosyst. Environ., 219, 179-189, 2016.

Cui, F., Zheng, X., Liu, C., Wang, K., Zhou, Z., and Deng, J.: Assessing biogeochemical effects and best management practice for a wheat-maize cropping system using the DNDC model, Biogeosciences, 11, 91-107, https://doi.org/10.5194/bg-11-912014, 2014.

Cui, Z., Zhang, H., Chen, X., Zhang, C., Ma, W., Huang, C., Zhang, W., Mi, G., Miao, Y., Li, X., Gao, Q., Yang, J., Wang, Z., Ye, Y., Guo, S., Lu, J., Huang, J., Lv, S., Sun, Y., Liu, Y., Peng, X., Ren, J., Li, S., Deng, X., Shi, X., Zhang, Q., Yang, Z., Tang, L., Wei, C., Jia, L., Zhang, J., He, M., Tong, Y., Tang, Q., Zhong, X., Liu, Z., Cao, N., Kou, C., Ying, H., Yin, Y., Jiao, X., Zhang, Q., Fan, M., Jiang, R., Zhang, F., and Dou, Z.: Pursuing sustainable productivity with millions of smallholder farmers, Nature, 555, 363-366, 2018.
Cuo, L., Zhang, Y., Bohn, T., Zhao, L., Li, J., Liu, Q., and Zhou, B.: Frozen soil degradation and its effects on surface hydrology in the northern Tibetan Plateau, J. Geophys. Res.-Atmos., 120, 8276-8298, 2015.

de Bruijn, A.M.G., Butterbach-Bahl, K., Blagodatsky, S., and Grote, R.: Model evaluation of different mechanisms driving freeze-thaw $\mathrm{N}_{2} \mathrm{O}$ emissions, Agr. Ecosyst. Environ., 133, 196207, 2009.

Deng, J., Li, C., Frolking, S., Zhang, Y., Bäckstrand, K., and Crill, P.: Assessing effects of permafrost thaw on $\mathrm{C}$ fluxes based on multiyear modeling across a permafrost thaw gradient at Stordalen, Sweden, Biogeosciences, 11, 4753-4770, https://doi.org/10.5194/bg-11-4753-2014, 2014.

Dong, Z., Hu, G., Yan, C., Wang, W., and Lu, J.: Aeolian desertification and its causes in the Zoige Plateau of China's QinghaiTibetan Plateau, Environ. Earth Sci., 59, 1731-1740, 2010.

Dubache, G., Li, S., Zheng, X., Zhang, W., and Deng, J.: Modeling ammonia volatilization following urea application to winter cereal fields in the United Kingdom by improving a biogeochemical model, Sci. Total Environ., 660, 1403-1418, 2019.

Farquhar, G., Caemmerer, S., and Berry, J.: A biochemical model of photosynthetic $\mathrm{CO}_{2}$ assimilation in leaves of $\mathrm{C}_{3}$ species, Planta, 149, 78-90, 1980.

Fenner, N. and Freeman, C.: Drought-induced carbon loss in peatlands, Nat. Geosci., 4, 895-900, 2011.

Foereid, B., Barthram, G., and Marriott, C.: The CENTURY model failed to simulate soil organic matter development in an acidic grassland, Nutr. Cycl. Agroecosyst., 78, 143-153, 2007.

Ford, T. W., Harris, E., and Quiring, S. M.: Estimating root zone soil moisture using near-surface observations from SMOS, Hydrol. Earth Syst. Sci., 18, 139-154, https://doi.org/10.5194/hess18-139-2014, 2014.

Galloway, J., Dentenerd, F., Capone, D., Boyer, E., Howarth, R., Seitzinger, S., Asner, G., Cleveland, C., Green, P., Holland, E., Karl, D., Michaels, A., Porter, J., Townsend, A., and Vorosmarty, C.: Nitrogen Cycles: past, present, and future, Biogeochemistry, 70, 153-226, 2004.

Galloway, J., Townsend, A., Erisman, J., Bekunda, M., Cai, Z., Freney, J., Martinelli, L., Seitzinger, S., and Sutton, M.: Transformation of the nitrogen cycle: recent trends, questions, and potential solutions, Science, 320, 889-892, 2008.

Giltrap, D.L., Li, C., and Saggar, S.: DNDC: A process-based model of greenhouse gas fluxes from agricultural soils, Agr. Ecosyst. Environ., 136, 292-300, 2010.

Gong, Y., Wu, J., Vogt, J., and Ma, W.: Greenhouse gas emissions from peatlands under manipulated warming, nitrogen addition, and vegetation composition change: a review and data synthesis, Environ. Rev., 28, 428-437, 2020.

Haas, E., Klatt, S., Fröhlich, A., Kraft, P., Werner, C., Kiese, R., Grote, R., Breuer, L., and Butterbach-Bahl, K.: LandscapeDNDC: a process model for simulation of biosphere-atmospherehydrosphere exchange processes at site and regional scale, Landsc. Ecol., 28, 615-636, 2012.

Hatano, R.: Impact of land use change on greenhouse gases emissions in peatland: a review, Int. Agrophys., 33, 167-173, 2019.

Holzworth, D., Huth, N., deVoil, P., Zurcher, E., Herrmann, N., McLean, G., Chenu, K., van Oosterom, E., Snow, V., Murphy, C., Moore, A., Brown, H., Whish, J., Verrall, S., Fainges, J., Bell, L., Peake, A., Poulton, P., Hochman, Z., Thorburn, P., Gay- 
don, D., Dalgliesh, N., Rodriguez, D., Cox, H., Chapman, S., Doherty, A., Teixeira, E., Sharp, J., Cichota, R., Vogeler, I., Li, F., Wang, E., Hammer, G., Robertson, M., Dimes, J., Whitbread, A., Hunt, J., van Rees, H., McClelland, T., Carberry, P., Hargreaves, J., MacLeod, N., McDonald, C., Harsdorf, J., Wedgwood, S., and Keating, B.: APSIM - Evolution towards a new generation of agricultural systems simulation, Environ. Modell. Softw., 62, 327-350, 2014.

Houska, T., Kraus, D., Kiese, R., and Breuer, L.: Constraining a complex biogeochemical model for $\mathrm{CO} 2$ and $\mathrm{N} 2 \mathrm{O}$ emission simulations from various land uses by model-data fusion, Biogeosciences, 14, 3487-3508, https://doi.org/10.5194/bg-143487-2017, 2017.

Huang, C.: Soil Science, China Agriculture Press, Beijing, 125 pp., 2000 (in Chinese).

Hugelius, G., Loisel, J., Chadburn, S., Jackson, R., Jones, M., MacDonald, G., Marushchak, M., Olefeldt, D., Maara, P., Siewert, M., Treat, C., Turetsky, M., Voigt, C., and Yu, Z.: Large stocks of peatland carbon and nitrogen are vulnerable to permafrost thaw, P. Natl. Acad. Sci. USA, 117, 20438-20446, https://doi.org/10.1073/pnas.1916387117, 2020.

IPCC (Intergovernmental Panel on Climate Change): Climate Change 2013: The Physical Science Basis, Contribution of Working Group I to the Fifth Assessment Report of the Intergovernmental Panel on Climate Change, edited by: Stocker, T. F., Qin, D., Plattner, G.-K., Tignor, M. B., Allen, S. K., Boschung,J., Nauels, A., Xiao, Y., Bex, V., and Midgley, P. M., Cambridge University Press, Cambridge, United Kingdom and New York, NY, USA, 2013.

Jiang, H., Yi, Y., Zhang, W., Yang, K., and Chen, D.: Sensitivity of soil freeze/thaw dynamics to environmental conditions at different spatial scales in the central Tibetan Plateau, Sci. Total Environ., 734, 139261, https://doi.org/10.1016/j.scitotenv.2020.139261, 2020.

Jiang, Z.: Analysis on the establishment conditions of the square sum decomposition formular of regression model, J. Industr. Techn. Econ., 29, 116-119, 2010 (in Chinese).

Johansen, O.: Thermal conductivity of soils, Ph.D. thesis, Univ. of Trondheim, Trondheim, Norway, 1975.

Ju, X., Xing, G., Chen, X., Zhang, S., Zhang, L., Liu, X., Cui, Z., Yin, B., Christie, P., Zhu, Z., and Zhang, F.: Reduing environmental risk by improveing $\mathrm{N}$ mannagement in intensive Chinese agricultural systems, P. Natl. Acad. Sci. USA, 106, 3041-3046, 2009.

Kandel, T., Lærke, P., and Elsgaard, L.: Annual emissions of $\mathrm{CO}_{2}$, $\mathrm{CH}_{4}$ and $\mathrm{N}_{2} \mathrm{O}$ from a temperate peat bog: comparison of an undrained and four drained sites under permanent grass and arable crop rotations with cereals and potato, Agr. Forest Meteorol., 256/257, 470-481, 2018.

Kang, X., Li, Y., Wang, J., Yan, L., Zhang, X., Wu, H., Yan, Z., Zhang, K., and Hao, Y.: Precipitation and temperature regulate the carbon allocation process in alpine wetlands: quantitative simulation, J. Soils Sediment., 20, 3300-3315, 2020.

Keiluweit, M., Wanzek, T., Kleber, M., Nico, P., and Fendorf, S.: Anaerobic microsites have an unaccounted role in soil carbon stabilization, Nat. Commun., 8, 1771, https://doi.org/10.1038/s41467-017-01406-6, 2017.

Klatt, S., Kraus, D., Kraft, P., Breuer, L., Wlotzka, M., Heuveline, V., Haas, E., Kiese, R., and Butterbach-Bahl, K.: Exploring im- pacts of vegetated buffer strips on nitrogen cycling using a spatially explicit hydro-biogeochemical modeling approach, Environ. Modell. Softw., 90, 55-67, 2017.

Li, B., Yu, Z., LIang, Z., Song, K., Li, H., Wang, Y., Zhang, W., and Acharya, K.: Effects of climate variations and human activities on runoff in the Zoige alpine wetland in the eastern edge of the Tibetan Plateau, J. Hydrol. Eng., 19, 1026-1035, 2014.

Li, C.: Modeling trace gas emissions from agricutural ecosystems, Nutr. Cycl. Agroecosyst., 58, 259-276, 2000.

Li, C.: Quantifying greenhouse gas emissions from soils: scientific basis and modeling approach, Soil Sci. Plant Nutr., 53, 344-352, 2007.

Li, C.: Biogeochemistry: Scientific Fundamentals and Modelling Approach, Tsinghua University Press, Beijing, 530 pp., 2016 (in Chinese).

Li, C., Frolking, S., and Butterbach-Bahl, K.: Carbon sequestration in arable soils is likely to increase nitrous oxide emissions, offsetting reductions in climate radiative forcing, Climatic Change, 72, 321-338, 2005.

Li, S., Zheng, X., Zhang, W., Han, S., Deng, J., Wang, K., Wang, R., Yao, Z., and Liu, C.: Modeling ammonia volatilization following the application of synthetic fertilizers to cultivated uplands with calcareous soils using an improved DNDC biogeochemistry model, Sci. Total Environ., 660, 931-946, 2019.

Li, Y., White, R., Chen, D., Zhang, J., Li, B., Zhang, Y., Huang, Y., and Edis, R.: A spatially referenced water and nitrogen management model (WNMM) for (irrigated) intensive cropping systems in the North China Plain, Ecol. Model., 203, 395-423, 2007.

Liu, C., Holst, J., Brüggemann, N., Butterbach-Bahl, K., Yao, Z., Yue, J., Han, S., Han, X., Krümmelbein, J., Horn, R., and Zheng, $\mathrm{X}$.: Winter-grazing reduces methane uptake by soils of a typical semi-arid steppe in Inner Mongolia, China, Atmos. Environ., 41, 5948-5958, 2007.

Liu, S., Xie, Z., Zeng, Y., Liu, B., Li, R., Wang, Y., Wang, L., Qin, P., Jia, B., and Xie, J.: Effects of anthropogenic nitrogen discharge on dissolved inorganic nitrogen transport in global rivers, Glob. Change Biol., 25, 1493-1513, 2019.

Ma, L., Yao, Z., Zheng, X., Zhang, H., Wang, K., Zhu, B., Wang, R., Zhang, W., and Liu, C.: Increasing grassland degradation stimulates the non-growing season $\mathrm{CO}_{2}$ emissions from an alpine meadow on the Qinghai-Tibetan Plateau, Environ. Sci. Pollut. Res., 25, 26576-26591, 2018.

McClain, M., Boyer, E., Dent, C., Gergel, S., Grimm, N., Groffman, P., Hart, S., Harvey, J., Johnston, C., and Mayorga, E.: Biogeochemical hot spots and hot moments at the interface of terrestrial and aquatic ecosystems, Ecosystems, 6, 301-312, 2003.

Moriasi, D., Arnold, J., Van Liew, M., Bingner, R., Harmel, R., and Veith, T.: Model evaluation guidelines for systematic quantification of accuracy in watershed simulation, T. Am. Soc. Agr. Biol. Eng., 50, 885-900, 2007.

Nash, J. and Sutcliffe, J.: River flow forecasting through conceptual models: part I - a discussion of principles, J. Hydrol., 10, 282 290, 1970.

Pansu, M., Sarmiento, L., Rujano, M., Ablan, M., Acevedo, D., and Bottner, P.: Modelling Organic transformations by MicroOrganisms of Soils in six contrasting ecosystems: validation of the MOMOS model, Global Biogechem. Cy., 24, GB1008, https://doi.org/10.1029/2009GB003527, 2010. 
Pansu, M., Machado, D., Bottner, P., and Sarmiento, L.: Modelling microbial exchanges between forms of soil nitrogen in contrasting ecosystems, Biogeosciences, 11, 915-927, https://doi.org/10.5194/bg-11-915-2014, 2014.

Piao, S., Fang, J., Ciais, P., Peylin, P., Huang, Y., Sitch, S., and Wang, T.: The carbon balance of terrestrial ecosystems in China, Nature, 458, 1009-1013, 2009.

Pohlert, T., Huisman, J., Breuer, L., and Frede, H.: Integration of a detailed biogeochemical model into SWAT for improved nitrogen predictions - Model development, sensitivity, and GLUE analysis, Ecol. Model., 203, 215-228, 2007.

Pollack, H. and Chapman, D.: On the regional variation of heat flow,geotherms, and lithospheric thickness, Teclonophysics, 38, 279-296, 1977.

Schroeck, A., Gaube, V., Haas, E., and Winiwarter, W.: Estimating nitrogen flows of agricultural soils at a landscape level - A modelling study of the Upper Enns Valley, a long-term socioecological research region in Austria, Sci. Total Environ., 665, 275-289, 2019.

Schuur, E., McGuire, A., Schadel, C., Grosse, G., Harden, J., Hayes, D., Hugelius, G., Koven, C., Kuhry, P., Lawrence, D., Natali, S., Olefeldt, D., Romanovsky, V., Schaefer, K., Turetsky, M., Treat, C., and Vonk, J.: Climate change and the permafrost carbon feedback, Nature, 520, 171-179, 2015.

Seitzinger, S.: Nitrogen cycle - Out of reach, Nature, 452, 162-163, 2008.

Song, L., Yao, Y., Lin, L., Gao, W., Cai, T., Liang, H., and Gao, D.: The potential source of nitrous oxide in the pristine riparian marsh during freeze-thaw cycles, case study in Northeast China, Ecol. Eng., 134, 18-25, 2019.

Tan, L., Ge, Z., Zhou, X., Li, S., Li, X., and Tang, J.: Conversion of coastal wetlands, riparian wetlands, and peatlands increases greenhouse gas emissions: a global meta-analysis, Glob. Change Biol., 26, 1638-1653, 2020.

Todd-Brown, K., Hopkins, F., Kivlin, S., Jennifer, M., Talbot, J., and Allison, S.: A framework for representing microbial decomposition in coupled climate models, Biogeochemistry, 109, 19-33, 2012.

Treseder, K., Balser, T., Bradford, M., Brodie, E., Dubinsky, E., Eviner, V., Hofmockel, K., Lennon, J., Levine, U., MacGregor, B., Pett-Ridge, J., and Waldrop, M.: Integrating microbial ecology into ecosystem models: challenges and priorities, Biogeochemistry, 109, 7-18, 2011.

Vereecken, H., Schnepf, A., Hopmans, J., Javaux, M., Or, D., Roose, T., Vanderborght, J., Young, M., Amelung, W., Aitkenhead, M., Allison, S., Assouline, S., Baveye, P., Berli, M., Brüggemann, N., Finke, P., Flury, M., Gaiser, T., Govers, G., Ghezzehei, T., Hallett, P., Hendricks Franssen, H., Heppell, J., Horn, R., Huisman, J., Jacques, D., Jonard, F., Kollet, S., Lafolie, F., Lamorski, K., Leitner, D., McBratney, A., Minasny, B., Montzka, C., Nowak, W., Pachepsky, Y., Padarian, J., Romano, N., Roth, K., Rothfuss, Y., Rowe, E., Schwen, A., Šimůnek, J., Tiktak, A., Van Dam, J., van der Zee, S., Vogel, H., Vrugt, J., Wöhling, T., and Young, I.: Modeling Soil Processes: Review, Key Challenges, and New Perspectives, Vadose Zone J., 15, vzj2015.09.0131, https://doi.org/10.2136/vzj2015.09.0131, 2016.

Wania, R., Ross, I., and Prentice, I.: Integrating peatlands and permafrost into a dynamicglobal vegetation model: 1. Evaluation and sensitivity of physical land surface processes, Global Biogechem. Cy., 23, GB3014, https://doi.org/10.1029/2008GB003412, 2009.

Wigmosta, M., Vail, L., and Lettenmaier, D.: A distributed hydrology-vegetation model for complex terrain, Water Resour. Res., 30, 1665-1679, 1994.

Willmott, C. and Matsuurra, K.: Advantages of the mean aboslute error (MAE) over the root mean square error (RMSE) in assessing average model performance, Clim. Res., 30, 79-82, 2005.

Wolf, B., Kiese, R., Chen, W., Grote, R., Zheng, X., and ButterbachBahl, K.: Modelling $\mathrm{N}_{2} \mathrm{O}$ emissions from steppe in Inner Mongolia, China, with consideration of spring thaw and grazing intensity, Plant Soil, 350, 297-310, 2011.

Wu, Y., Liu, S., Qiu, L., and Sun, Y.: SWAT-DayCent coupler: An integration tool for simultaneous hydro-biogeochemical modeling using SWAT and DayCent, Environ. Modell. Softw., 86, 8190, 2016.

Xiang, S., Guo, R., Wu, N., and Sun, S.: Current status and future prospects of Zoige Marsh in Eastern Qinghai-Tibet Plateau, Ecol. Eng., 35, 553-562, 2009.

Yao, Z., Ma, L., Zhang, H., Zheng, X., Wang, K., Zhu, B., Wang, R., Wang, Y., Zhang, W., Liu, C., and Butterbach-Bahl, K.: Characteristics of annual greenhouse gas flux and NO release from alpine meadow and forest on the eastern Tibetan Plateau, Agr. Forest Meteorol., 272/273, 166-175, 2019.

Zhang, H., Yao, Z., Wang, K., Zheng, X., Ma, L., Wang, R., Liu, C., Zhang, W., Zhu, B., Tang, X., Hu, Z., and Han, S.: Annual $\mathrm{N}_{2} \mathrm{O}$ emissions from conventionally grazed typically alpine grass meadows in the eastern QInghai-Tibetan Plateau, Sci. Total Environ., 625, 885-899, 2018.

Zhang, H., Yao, Z., Ma, L., Zheng, X., Wang, R., Wang, K., Liu, C., Zhang, W., Zhu, B., Tang, X., Hu, Z., and Han, S.: Annual methane emissions from degraded alpine wetlands in the eastern Tibetan Plateau, Sci. Total Environ., 657, 1323-1333, 2019.

Zhang, W., Liu, C., Zheng, X., Fu, Y., Hu, X., Cao, G., and Butterbach-Bahl, K.: The increasing distribution area of zokor mounds weaken greenhouse gas uptakes by alpine meadows in the Qinghai-Tibetan Plateau, Soil Biol. Biochem., 71, 105-112, 2014.

Zhang, W., Liu, C., Zheng, X., Zhou, Z., Cui, F., Zhu, B., Haas, E., Klatt, S., Butterbach-Bahl, K., and Kiese, R.: Comparison of the DNDC, LandscapeDNDC and IAP-N-GAS models for simulating nitrous oxide and nitric oxide emissions from the winter wheat-summer maize rotation system, Agr. Syst., 140, 1-10, 2015.

Zhang, W., Li, Y., Zhu, B., Zheng, X., Liu, C., Tang, J., Su, F., Zhang, C., Ju, X., and Deng, J.: A process-oriented hydrobiogeochemical model enabling simulation of gaseous carbon and nitrogen emissions and hydrologic nitrogen losses from a subtropical catchment, Sci. Total Environ., 616/617, 305-317, 2018.

Zhang, W., Liu, C., Zheng, X., Wang, K., Cui, F., Wang, R., Li, S., Yao, Z., and Zhu, J.: Using a modified DNDC biogeochemical model to optimize field management of a multi-crop (cotton, wheat, and maize) system: a site-scale case study in northern China, Biogeosciences, 16, 2905-2922, https://doi.org/10.5194/bg-16-2905-2019, 2019.

Zhang, W., Wang, J., Hu, Z., Li, Y., Yan, Z., Zhang, X., Wu, G., Yan, L., Zhang, K., and Kang, X.: The primary drivers of greenhouse gas emissions along the water table gradient in 
the Zoige apline peatland, Water Air Soil Pollut., 231, 224, https://doi.org/10.1007/s11270-020-04605-y, 2020.

Zhang, Y., Chen, W., and Cihlar, J.: A process-based model for quantifying the impact of climate change on permafrost thermal regimes, J. Geophys. Res.-Atmos., 108, 4695, https://doi.org/10.1029/2002JD003354, 2003.

Zhang, Y., Sachs, T., Li, C., and Boike, J.: Upscaling methane fluxes from closed chambers to eddy covariance based on a permafrost biogeochemistry integrated model, Glob. Change Biol., 18, 1428-1440, 2012.

Zhang, Y. Y., Shao, Q. X., Ye, A. Z., Xing, H. T., and Xia, J.: Integrated water system simulation by considering hydrological and biogeochemical processes: model development, with parameter sensitivity and autocalibration, Hydrol. Earth Syst. Sci., 20, 529553, https://doi.org/10.5194/hess-20-529-2016, 2016.
Zhu, Q., Schmidt, J. P., and Bryant, R.: Hot moments and hot spots of nutrient losses from a mixed land use watershed, J. Hydrol. Eng., 414, 393-404, 2012.

Zhu, Q., Castellano, M., and Yang, G.: Coupling soil water processes and the nitrogen cycle across spatial scales: potentials, bottlenecks and solutions, Earth-Sci. Rev., 187, 248-258, 2018.

Zhuang, Q., Romanovsk, V., and McGuire, A.: Incorporation of a permafrost model into a large-scale ecosystem model: Evaluation of temporal and spatial scaling issues in simulating soil thermal dynamics, J. Geophys. Res., 106, 33649-33670, 2001.

Zhuang, Q., Melillo, J., Kicklighter, D., Prinn, R., McGuire, A., Steudler, P., Felzer, B., and Hu, S.: Methane fluxes between terrestrial ecosystems and the atmosphere at northern high latitudes during the past century: a retrospective analysis with a process-based biogeochemistry model, Global Biogechem. Cy., 18, GB3010, https://doi.org/10.1029/2004GB002239, 2004. 